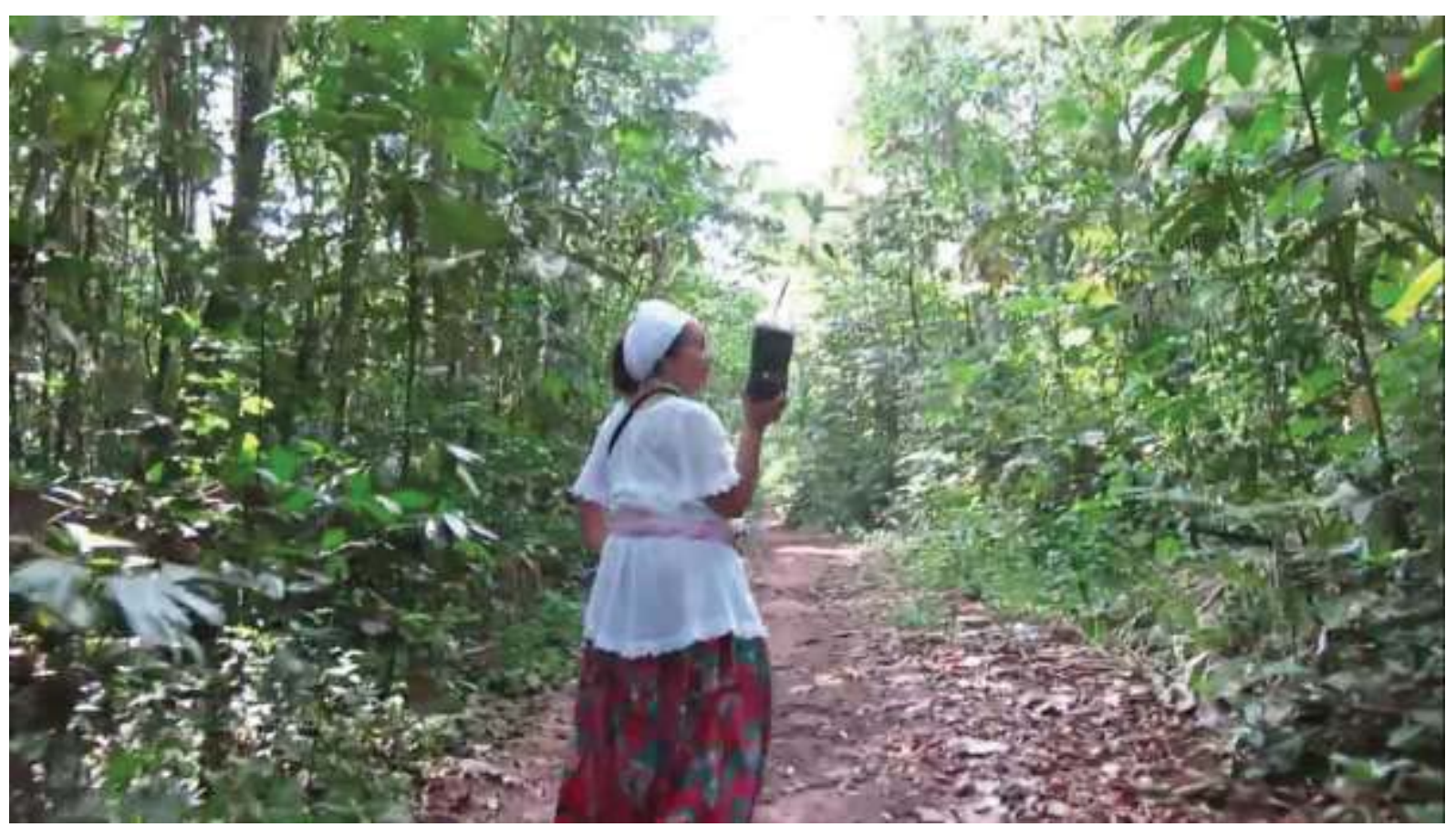

\title{
MAMETU NANGETU NA MATA
}

\section{MAMETU NANGETU ON FOREST}

\author{
Pedro Olaia e Wellington Romario
}

SINOPSE: Comunidades tradicionais de matriz africana tem uma profunda relação com a natureza e seus elementos. A região de floresta no entorno da feira da CEASA é frequentada por povos das comunidades tradicionais tanto para busca de folhas, cascas e ervas que a mata dá quanto para oferenda e agradecimento aos seres e energias da mata. Mametu Nangetu é uma mulher de tradição que frequenta a CEASA desde quando era criança, e tem uma intimidade estreita com o espaço; além de colher o que a natureza nos presenteia, muitas vezes leva mudas para reflorestar algumas áreas já degradadas. Este vídeo é o registro etnográfico realizado durante o processo de pesquisa do projeto: "Feira Livre; -performa-te cidade: investigação performática, diálogos e outros sabores" contemplado pela Bolsa de Criação, Experimentação, Pesquisa e Divulgação Artística 2015 da Fundação Cultural do Pará. Este registro foi realizado em uma manhã do mês de outubro deste ano de 2015 na feira e mata da CEASA com a comunidade do Mansu Nangetu, onde pudemos acompanhar Mametu Nangetu compartilhando saberes da nossa tradição bantu. Katendê é o Senhor das florestas e das Jinsaba, as folhas sagradas. Mariô é a folha do dendezeiro e é utilizado nas entradas dos terreiros de candomblé. Utilizou-se para a captura das imagens uma máquina CANON G15.

PALAVRAS-CHAVE: Tradição, Feira, Mata

SYNOPSIS: Traditional communities of African array has a deep relationship with nature and its elements. The forest surrounding the market-place "CEASA" is attended by people from traditional communities. They collect leaves, bark and herbs that the forest gives and offer thanks to the energies and mystics persons of the forest. Mametu Nangetu is a tradition woman that goes to the market-place CEASA sinc she was kid, she has great intimacy with 
the space. She reaps what nature presents us and also afforests the place. This video is the ethnographic record by during the research process of the project: "Feira Livre; -performa-te cidade: investigação performática, diálogos e outros sabores". This project was awarded by "Bolsa de Criação, Experimentação, Pesquisa e Divulgação Artística 2015 da Fundação Cultural do Pará". This record was achieved in one morning we were with the Mansu Nangetu's community at the CEASA's fair and forest, and we follow Mametu Nangetu sharing knowledge of our bantu tradition. Katendê is the Lord of Forests and Lord of Jinsaba, the sacred leaves. Mariô is the oil palm leaf and it's used at the entrances of candomble houses. A CANON G15 machine was used to capture the images.

KEYWORDS: Tradition; Market-place; Forest

\section{Ficha Técnica:}

Produção: Pedro Olaia e Wellington Romario

Imagens/Operadora de Câmera: Luana Beatriz Lima Peixoto

Edição: Pedro Olaia

Roteirista/Texto: Mametu Nangetu

Credits:

Production: Pedro Olaia and Wellington Romario

Images/Cameraperson: Luana Beatriz Lima Peixoto

Edition: Pedro Olaia

Scriptwriter/Text: Mametu Nangetu

LINK PARA ACESSO:

https://youtu.be/yXI_KIOnpRU

https://vimeo.com/217988971 